\title{
DESIGN AND FABRICATION OF AN ELECTRICALLY POWERED MAIZE PLANTER
}

\author{
BABATUNDE OLUWAMAYOKUN SOYOYE ${ }^{* 1}$ \\ ${ }^{1}$ Agricultural and Environmental Engineering Department, Federal University of \\ Technology, P. M. B. 704 Akure Ondo State Nigeria
}

\begin{abstract}
The correct application of production inputs for environmental and agricultural production sustainability is a key to successful production of maize. An electrically powered maize planter was designed and fabricated. Light reflecting optoelectronic field counter capable of detecting free falling object with equivalent or greater than $0.7 \mathrm{~mm}$ distance in planter delivery tube was designed and built to monitor seed drop on the planter. The device accurately counted the falling seeds with the planter forward speed of $1.38 \mathrm{~m} / \mathrm{s}$ and seed delivery tube of $24 \mathrm{~mm}$. The average number of two seeds was discharged per hole.
\end{abstract}

Keywords: optoelectronic, counter, space uniformity, maize grain, application rate, discharge rate

\section{INTRODUCTION}

Maize is one of the popular staple foods in Nigeria and also serves as an important raw material for industries. It is processed in different forms as livestock feed. It is also an important source of carbohydrate, protein, iron, vitamin B, and minerals [1]. Nigerians as well as other Africans consume maize as a starchy base in a wide variety of porridges, pastes, grits and beer. Fresh maize could be eaten parched, baked, roasted or boiled. In Nigeria planting of maize is still largely carried out by traditional and manual methods [2]. Drudgery and time wasting are associated with the manual methods of planting [3].

Planting is the process of placing (putting) seeds in the soil for good germination in the field. The manual method of planting is a tedious job and resulted in inaccurate seed placement and spacing and resulted in general body pain for the farmer $[4,5]$. Planter is a device which helps in the placement of seeds in a desired position, thereby assisting the farmers in saving time and money $[6,7]$.

\subsection{Existence of planter}

Sowing or planting begun with the early men using the bare hands and later graduated to the use of sticks then to the use of crude implements like cutlasses and hoes for planting and the general tillage operations. Efforts have been put in place to simplify human labour overtime in sowing seeds by the innovations of seed planters [3].

Drill planters randomly drop seeds in furrows to form definite rows of established plants. This type of planter uses a mass flow type seed meter and is extensively used for the establishment of both winter and summer crops where there is no need to place plants equidistant down the rows $[8,9]$. Reasonably accurate control over the planting rate per hectare can be attained. Drill type planters are often known as solid crop planters because of the narrow row spacing typically used [10]. Precision planters place single seed or group of seeds accurately at almost equal distant apart along the furrow. They are typically used to plant crops that require accurate control of plant

\footnotetext{
* Corresponding author, email: soyoye2002@yahoo.com, bosoyoye@ futa.edu.ng

(C) 2020 Alma Mater Publishing House
} 
population and inter-row and intra-row spacing. Crops in this category include almost all the horticultural crops and field crops such as sorghum, maize, sunflower, soybeans and cotton [10,11]. Many of the crops requiring the use of precision planters grown in summer are planted in wide rows and have individual seed boxes and associated seed meters for each row. Accordingly, precision planters are often referred to as summer crop planters, row crop planters or unit planters respectively [10].

\subsection{Research aim and objectives}

The main aim of this research is to design and fabricate a single row motor assisted maize planter for the purpose of reducing drudgery in crop production and for the use of peasant farmers. The specific objectives of the research are to:

- Design and fabricate the components of the planter using locally available materials.

- Design a display unit for monitoring the performance of the planter.

- Assemble and test the planter.

\subsection{Research justification}

Seed planting machine is a device which helps in the sowing of seeds in a desired position, thereby assisting the farmers in saving time and manpower. In order to reduce drudgery and to increase yield, the old methods of planting must be reduced to its barest minimum and the new method which is the use of mechanically operated planter must be embraced. The manual methods of planting resulted in drudgery and low income for the farmers. Therefore, in order to reduce the drudgery of manual planting and to fulfill the objectives of sowing operation, it is necessary to develop a motorized single row maize planter.

\section{EXPERIMENTAL SETUP}

\subsection{Description of the planter}

The components of the planter include: the frame, feeding hopper, furrow opener, furrow closer, metering device, shaft, bearings, sensor device, solar panel, $12 \mathrm{v}$ battery, rotary front and rear wheels. The machine frame holds every other components of the machine together, the feeding hopper serves as a container for the seed to be planted. The metal casing attached to the base of the hopper serves as housing for the metering device. The metering device functions to meter the right quantity of seeds into the furrow. It was made with mahogany wood and has four cells to contain two seeds per cell. Attached to the casing is the delivery tube of a cylindrical shape which serves as an outlet for the seeds from the metering device into the opened furrow. A light emitting diode and light dependent resistor was coupled to the delivery tube of the planter. This helped in the counting and monitoring the flow of seeds along the delivery tube. The planter has a handle which is used to control the direction the farmer intends it to go with the help of the rotary wheel (Figure 1). The orthographic and exploded drawings of the designed planter are shown in Figures 8 and 9.

\subsection{Design analysis}

The innovative information obtained from literatures, thesis, models, laboratory experiments along with experience and innovative ideas used by Soyoye et al. [1,3] in the manually operated vertical seed-plate maize planter were applied in the conception of the machine described in Figure 1.
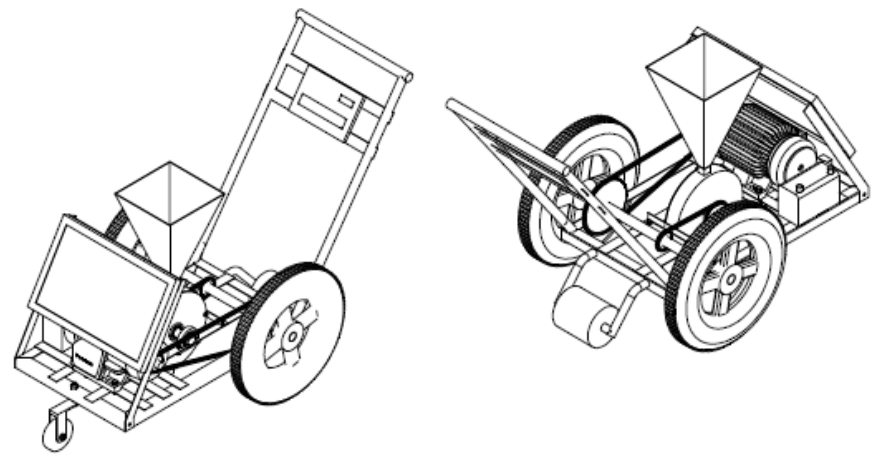

Fig. 1. Conceptual design of the planter: 1 - solar panel; 2 - hopper; 3 - display unit; 4 - handle; 5 - chain and sprocket; 6 - metering unit; 7 - electric motor; 8 - battery; 9 - soil firming device. 


\subsection{Determination of the planter push force}

The force required to push the planter was obtained from the following expressions [1] (Figure 2).

$$
\begin{gathered}
\Sigma H=P \cos \theta-R \cos \phi-R_{h}=0 \\
\Sigma V=R \sin \phi-P \sin \theta-W=0
\end{gathered}
$$

where: $P$ is the planter push force $(N), R_{h}$ is the Horizontal soil resistance force $(N), R$ is the soil frictional resistance force $(\mathrm{N}), \phi$ is the angle of friction $\left(^{\circ}\right), \theta$ is the angle between planter handle and the horizontal plane $\left(^{\circ}\right), \mathrm{W}$ is the weight of planter $(\mathrm{N}), \Sigma \mathrm{H}$ is the sum of horizontal forces acting on the planter $(\mathrm{N})$ and $\Sigma \mathrm{V}$ is the sum of vertical forces acting on the planter $(\mathrm{N})$.

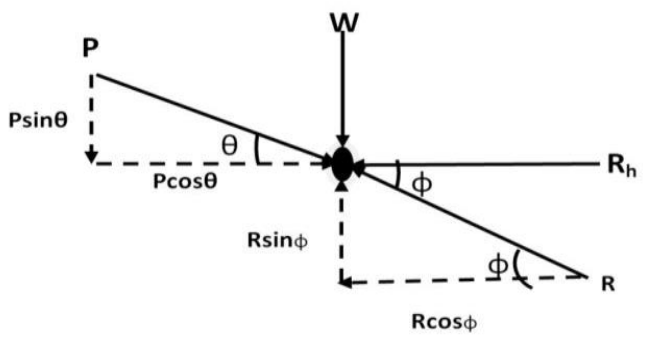

Fig. 2. Forces acting on the planter [1].

$$
\begin{gathered}
P=\frac{R \cos \phi+R_{h}}{\cos \theta} \\
R=\frac{R_{h} \tan \theta+W}{(\sin \theta-\cos \phi \tan \theta)}
\end{gathered}
$$

$\mathrm{R}$ and $\mathrm{P}$ were calculated to be $460 \mathrm{~N}$ and $438 \mathrm{~N}$ respectively.

The power required to operate the planter at a forward speed of $1.38 \mathrm{~m} / \mathrm{s}$ was calculated to be $604.44 \mathrm{~W}(0.6 \mathrm{~kW})$. Therefore $1 \mathrm{hp} \mathrm{dc}$ motor was used to power the planter.

\subsection{Instrumentation design}

\subsubsection{AT89C51 microcontroller}

The AT89C51 is a low-power, high-performance CMOS 8-bit microcomputer with 4K bytes of Flash programmable and erasable read only memory (PEROM). The device is made up of high-density nonvolatile memory technology. The onchip Flash allows the program memory to be reprogrammed in-system or by a conventional nonvolatile memory programmer. By combining a versatile 8-bit CPU with Flash on a monolithic chip, the Atmel AT89C51 is a powerful microcontroller which provides a highly-flexible and cost-effective solution to many embedded control applications. The microcontroller programming was done as follows (Figure $3)$.

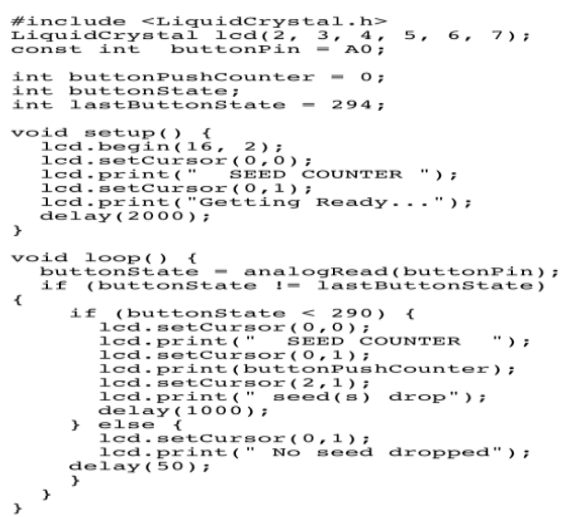

2.4.2. Sensor for seed counting description

Fig. 3. The microcontroller programming. 
The seed counting sensor for the planter comprises of an infrared emitter, LDR, microcontroller, electrolytic capacitor, ceramic capacitor, veroboard, regulator, voltage divider network, IC-40338 and a sixteen-segment display unit. The detailed circuit diagram is shown in Figure 4. The infrared emitter was flushed with one side of the seed delivery tube and just opposite to that is the LDR flushed to the other side and was mounted as shown in Plate 1 (Figure 5). When seed falls inside the tube it experiences a downward force from gravity which makes it passes between the LDR and the light emitting diode, the seeds obstructs the light falling on the LDR, current flows then causes the voltage at pin no. 1 to drop to a lower value which indicate obstruction and pulse is generated. When the seed passed through this point the light coming from the emitter falls back on the LDR then, the flow of current continues and voltage at pin number 1 will be at its initial range. The IC- 40338 sense the pulse, decode and send the signal to the sixteen segment display unit where the seed dropping will be displayed in number cumulatively as programmed (Plate 2, Figure 6). The assembled planter is shown in Plate 3 (Figure 7).

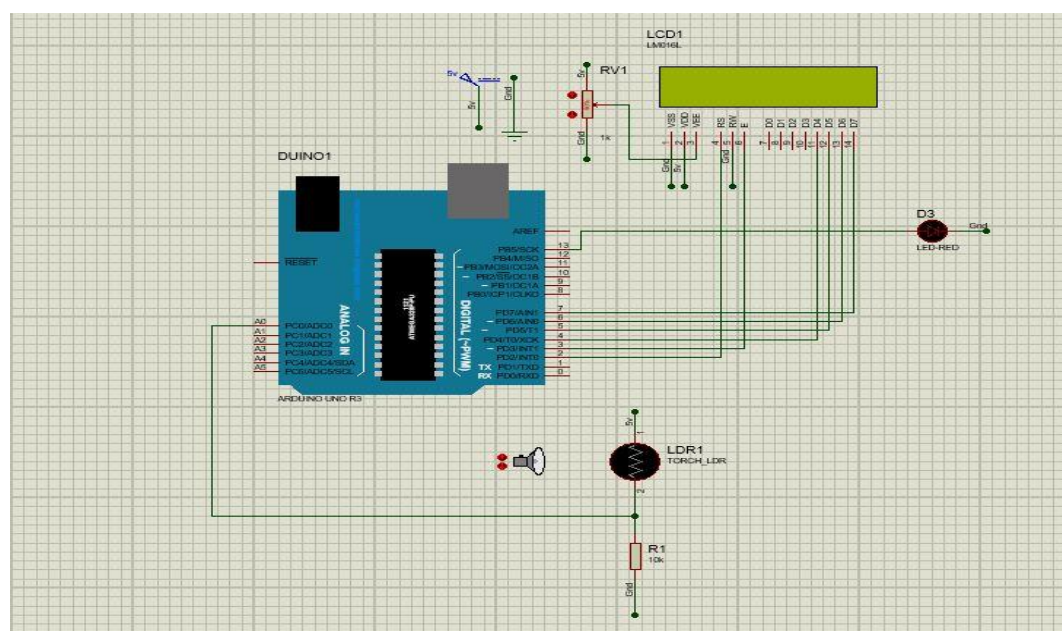

Fig. 4. Diagram of the Seed Counter Sensor.

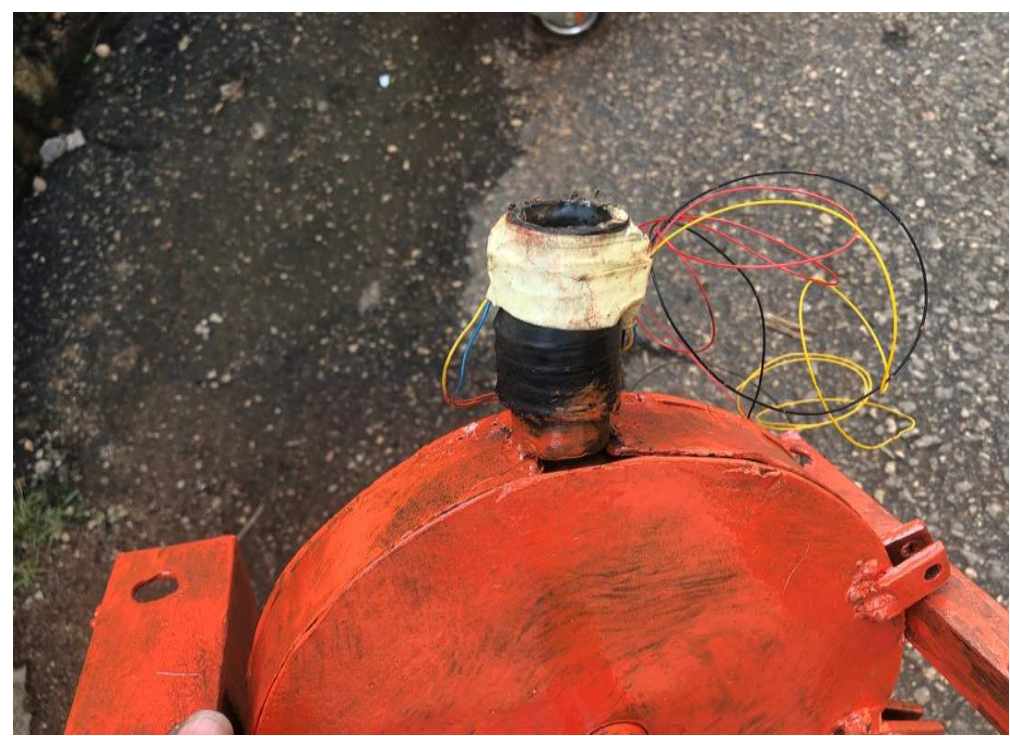

Fig. 5. Plate 1 - infrared light in seed delivery tube.

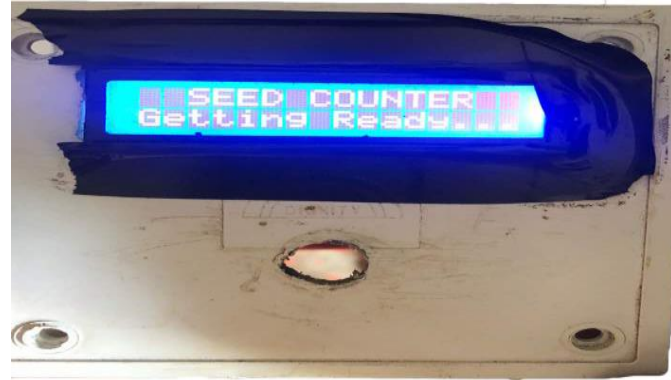


Fig. 6. Plate 2 - seed counter display device.

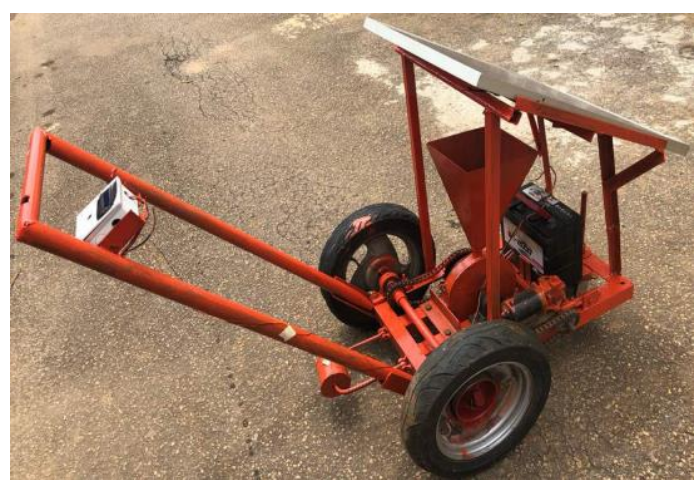

Fig. 7. Plate 3 - the fabricated planter.

\section{RESULTS AND DISCUSSION}

\subsection{Laboratory tests results}

The laboratory determination of uniformity of seed spacing in row and number of seeds dropping as counted and recorded by the sensing device are presented in Tables 1 and 2 . The results indicate that the planter sow averagely 2 seeds per hole, the number of seeds drop from the metering device were recorded and their spacing were practically measured with the aid of tape rule. The average seed spacing was recorded to be $15.63 \mathrm{~cm}$ which is closer to the calibrated spacing design of the metering device which is $15 \mathrm{~cm}$. The little deviation in the expected value may be as a result of inaccurate spacing of cell location on the metering device. The interference of reflected infrared light form internal wall and surrounding materials with infrared light signals of seeds was eliminated by using a dark black rubber hose around the sensor light detection set. The absorbing material could absorb 97\% of the interfering reflected light and correct counting errors caused by reflected light form non-target materials. The efficiency of sensor device was determined to be $95 \%$ due to overlapping of seeds from cell and the speed at which the planter was operated. The percentage seed damage was calculated to be $18 \%$, this may be due to uneven grade of seed that was fed into the hopper, another cause may be as a result of abrasion between the metering device and its plate i.e. metering device housing wall. Finally, the overall sowing efficiency of the planter was calculated to be $78 \%$.

Table 1. First laboratory test.

\begin{tabular}{|l|c|c|c|c|c|}
\hline S/N & $\begin{array}{c}\text { No. of seeds dropped } \\
\text { at the delivery tube }\end{array}$ & $\begin{array}{c}\text { Speed } \\
(\mathrm{m} / \mathrm{s})\end{array}$ & $\begin{array}{c}\text { Seed spacing } \\
(\mathrm{cm})\end{array}$ & $\begin{array}{c}\text { No. of damaged } \\
\text { seeds }\end{array}$ & $\begin{array}{c}\text { Sensor counts per } \\
\text { hole }\end{array}$ \\
\hline 1 & 2 & 2.8 & 14.4 & 0 & 2 \\
\hline 2 & 2 & 2.8 & 15.2 & 0 & 2 \\
\hline 3 & 2 & 2.8 & 15.7 & 1 & 2 \\
\hline 4 & 2 & 2.8 & 15.5 & 0 & 2 \\
\hline 5 & 2 & 2.8 & 15.7 & 1 & 2 \\
\hline 6 & 3 & 2.8 & 13.7 & 0 & 2 \\
\hline 7 & 2 & 2.8 & 18.1 & 0 & 2 \\
\hline 8 & 2.8 & 14.8 & 1 & 2 \\
\hline 9 & 2 & 2.8 & 15.4 & 0 & 21 \\
\hline 10 & 22 & 2.8 & 16.3 & 0 & 2.1 \\
\hline Total & 2.2 & 28 & 154.8 & & \\
\hline Mean & 2.8 & 15.48 & & \\
\hline
\end{tabular}

Percentage damaged seed $=\frac{\text { Total number of damaged seed }}{\text { Total number of discharged seed }} \times 100=\frac{3}{22} \times 100=13.64 \approx 14 \%$

Functional efficiency $=\frac{\text { Total number of discharged seed }- \text { Damaged seed }}{\text { Total number of discharged seed }} \times 100==\frac{22-3}{22} \times 100=\frac{19}{22} \times 100=$ $86 \%$

Spacing efficiency $=\frac{\text { Expected spacing }}{\text { Derived spacing }} \times 100=\frac{15}{15.48} \times 100=97 \%$ 
Sensor efficiency $=\frac{\text { Seeds counted by sensing device }}{\text { seeds } \text { dropped to the ground }} \times 100=\frac{21}{22} \times 100=96 \%$.

Table 2. Second laboratory test.

\begin{tabular}{|l|c|c|c|c|c|}
\hline S/N & $\begin{array}{c}\text { No. of seeds dropped at } \\
\text { the delivery tube }\end{array}$ & $\begin{array}{c}\text { Speed } \\
(\mathrm{m} / \mathrm{s})\end{array}$ & $\begin{array}{c}\text { Seed spacing } \\
(\mathrm{cm})\end{array}$ & $\begin{array}{c}\text { No. of damaged } \\
\text { seeds }\end{array}$ & $\begin{array}{c}\text { Sensor counts } \\
\text { per hole }\end{array}$ \\
\hline 1 & 2 & 2.8 & 13.4 & 0 & 2 \\
\hline 2 & 3 & 2.8 & 17.2 & 1 & 3 \\
\hline 3 & 2 & 2.8 & 15.7 & 0 & 2 \\
\hline 4 & 2 & 2.8 & 16.5 & 2 & 2 \\
\hline 5 & 3 & 2.8 & 14.7 & 1 & 2 \\
\hline 6 & 3 & 2.8 & 15.5 & 0 & 2 \\
\hline 7 & 2 & 2.8 & 15.4 & 0 & 3 \\
\hline 8 & 3 & 2.8 & 14.6 & 1 & 2 \\
\hline 9 & 2 & 2.8 & 18.4 & 0 & 2 \\
\hline 10 & 2 & 2.8 & 15.4 & 0 & 22 \\
\hline Total & 24 & 28 & 156.8 & 5 & 2.2 \\
\hline Mean & 2.4 & 2.8 & 15.67 & 1 & \\
\hline
\end{tabular}

Percentage damaged seed $=\frac{\text { Total number of damaged seed }}{\text { Total number of discharged seed }} \times 100=\frac{5}{22} \times 100=22.73 \approx 23 \%$

Functional efficiency $=\frac{\text { Total number of discharged seed-Damaged seed }}{\text { Total number of discharged seed }} \times 100=\frac{24-5}{24} \times 100=\frac{19}{24} \times 100=$ $79 \%$

Spacing efficiency $=\frac{\text { Expected spacing }}{\text { Derived } \text { spacing }} \times 100=\frac{15}{15.67} \times 100=96 \%$

Sensor efficiency $=\frac{\text { Number of seeds counted by sensor device }}{\text { Number of seeds dropped to the ground }} \times 100=\frac{22}{24} \times 100=92 \%$

\subsection{Estimation of theoretical or laboratory seed population and sowing efficiency}

The seed population was determined by $P a=\left[\frac{L B}{S r S C}\right]$ [3].

where $\mathrm{Pa}$ is actual seed population.

Average number of discharged seed $=2$

$\mathrm{LB}=$ length $=$ length $\times$ breadth $($ area of the field $)$

$\mathrm{Sr}$ and $\mathrm{Sc}=$ inter-row and intra-row spacing respectively $\mathrm{Sr}=50 \mathrm{~cm} \mathrm{[3].}$

Estimating the mean total spacing, we have $S c=\frac{15.48+15.62+15.75+15.67}{4}=15.63 \mathrm{~cm}$

Testing for an area of $4 \mathrm{~m} \times 4 \mathrm{~m}=8 \mathrm{~m}^{2}$

$\mathrm{Pa}=2\left[\frac{8}{0.154 \times 0.5}\right]=208$ seeds

The expected planting population (theoretical seed population) using the same formula with the designed spacing of $15 \mathrm{~cm}$ was calculated as $\mathrm{Pa}=2\left[\frac{8}{0.15 \times 0.5}\right]=213$ seeds.

The sowing efficiency of the machine regarding the considerable field area is given as:

$$
\frac{\text { Laboratory seed population }}{\text { Theoretical seed population }}=\frac{208}{213} \times 100=97.65 \%
$$

The total planter efficiency $=$ Average functional efficiency $\times$ sowing efficiency $=$

$$
=(0.8 \times 0.9765) \times 100=78 \%
$$

Hence total sowing efficiency of the machine $=78 \%$. 


\section{CONCLUSIONS}

The electrically powered single row maize planter incorporated with a seed counter sensor was designed and fabricated using locally available materials. The planter was estimated to have a sowing efficiency of $78 \%$ with an average spacing of $15.63 \mathrm{~cm}$. The metering unit was able to drop two seeds per hole and the optoelectronic counter sensor (Figure 8) was 95\% efficient which means it counts seeds as it drops almost precisely. The other electrical components incorporated on the planter such as solar panel (Figure 9), a 12V battery and the switch worked sufficiently to provide the appropriate current and voltage for the dc electric motor of the planter to perform effectively.
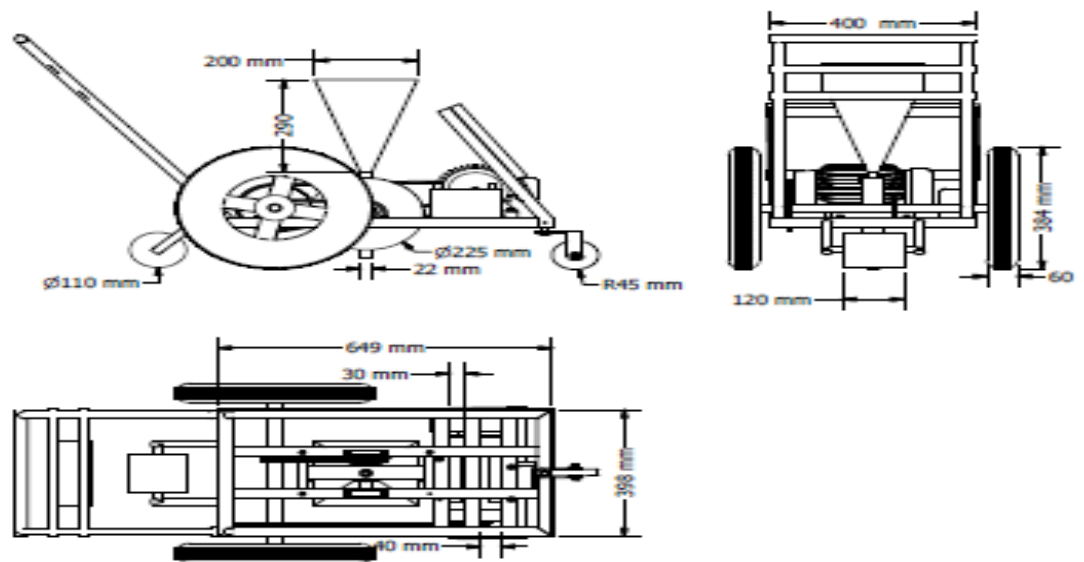

Fig. 8. Orthographic view of the planter.

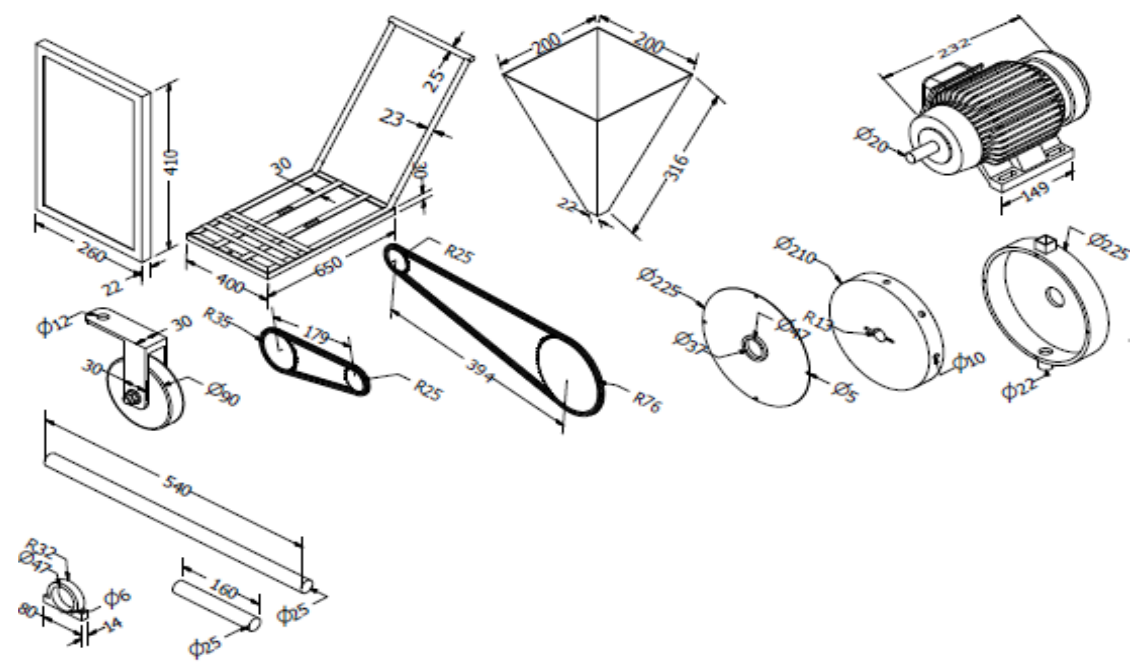

Fig. 9. Exploded view of the planter.

Acknowledgement: The author wish to appreciate the Tertiary Education Trust Fund (Tetfund) Nigeria through the Federal University of Technology, Akure (FUTA) for the fund released towards the execution of this research work.

\section{REFERENCES}

[1] Ani, O.A., Uzoejinwa, B.B., Anochili, N.F., Design, construction and evaluation of a vertical plate maize seed planter for gardens and small holder farmers, Nigerian Journal of Technology, vol 35, 2016, p. 647 - 655.

[2] Karayel, D., Özmerzi, A., Effect of forward speed and seed spacing uniformity on a precision vacuum metering unit for melon and cucumber seeds, Journal of Faculty of Agriculture, vol. 14, no. 2, 2001, p. 63-67. 
[3] Soyoye, B.O., Ademosun, O.C., Olu-Ojo, E.O., Manually operated vertical seed-plate maize planter, Agricultural Engineering International: CIGR Journal, vol. 18, no. 4, 2016, p. 70-80.

[4] Bahnasy, A.F., Aboukarima, A.M., Morsi, M.E., Abd El Halis, S.N., Development of a simple laboratory unit for calibration and testing seed drills, Journal of Agricultural Science Mansoura University, vol. 32, no. 12, 2007, p. 10109-10117.

[5] Kumar, A., Moses, S.C., Khan, K., A survey on the design, fabrication and utilization of different types of foods and vegetables dryer, IOSR Journal of Agriculture and Veterinary Science, vol. 8, no. 4, 2015, p. 2319-2372. [6] Alchanatis, V., Kashti, Y., Brikman, R., A machine vision for evaluation of planter seed spatial distribution, Agricultural Engineering International: CIGR Journal, vol. 4, 2002, p. 11-20.

[7] Oduma1, O., Ede, J.C., Igwe, J.E., Development and performance evaluation of a manually operated cowpea precision planter, International Journal of Engineering and Technology, vol. 4, no. 12, 2014, p. 693-699.

[8] Aboukarima, A.M., Abd El Halim, S.N., Morghany, H.A., Uncertainty valuation of seeding rate during laboratory testing of seed drill, Journal of Agricultural Science Mansoura University, vol. 33, no. 8, 2008, p. 57915808.

[9] Chen, Y., Tessier, S., Irvine, B., Drill and crop performances as affected by different drill configurations for no-till seeding, Soil and Tillage Research, vol. 77, no. 2, 2004, p. 147-155.

[10] Murray, J.R., Tullberg, J.N., Basnet, B.B., Planters and their components: types, attributes, functional requirements, classification and description, ACIAR Monograph, no. 121, 2006.

[11] Soyoye, B.O., Development and performance evaluation of an instrumented motorized multi-grain crop planter, Thesis, School of Post Graduate, Federal University of Technology Akure, 2018. 